\title{
De illusie van
}

onafhankelijkheid

Over het effectief functioneren van de

Raad van Commissarissen en de relevantie van de code Tabaksblat

\section{Theo Postma en Hans van Ees}

SAMENVATTING De aanbevelingen van de code Tabaksblat zijn ontleend aan 'best practices'. De vraag rijst waarop 'best practices' zijn gebaseerd en wat er mee wordt beoogd. In dit artikel zal worden betoogd dat de code mogelijk de legitimiteit van corporate governance instituties, in het bijzonder de Raad van Commissarissen (RvC), vergroot, maar niet noodzakelijkerwijs het effectief functioneren van deze instituties. De argumentatie hiervoor is dat de code Tabaksblat vooral richtlijnen over de RvC geeft en weinig over het daadwerkelijke gedrag van de raad zegt. De resultaten van wetenschappelijk onderzoek naar de relatie tussen kenmerken van de RvC en de prestatie van de onderneming laten geen eenduidige interpretatie toe. Daartoe is vooral meer onderzoek nodig naar de onderlinge relatie tussen dergelijke kenmerken enerzijds en de besluitvormingsprocessen en activiteiten van de Raad anderzijds. Gepleit wordt voor onderzoek dat zich richt op het openen van deze Black box. Dit wordt toegelicht aan de hand van de discussie inzake onafhankelijkheid van commissarissen. Onze conclusie is dat de formele behandeling van het begrip onafhankelijkheid in de code Tabaksblat waarschijnlijk niet het beoogde effect zal sorteren. Dit vanwege de te beperkte invulling van het begrip en de veronachtzaming van de meer procesmatige aspecten van het functioneren van de RvC. Een vervolgcode zou naar onze mening meer moeten inspelen op hoe commissarissen met elkaar en met de raad van bestuur omgaan. Onafhankelijkheid wordt dan meer benaderd in termen van mentale onafhankelijkheid, 'dingen anders zien', goed geïnformeerd willen zijn en het denken van bestuurders willen uitdagen. Dit vraagt betrokkenheid van commissarissen en leiderschap van de voorzitter van de RvC. Op deze punten kunnen opleidingen voor commissarissen ook een rol spelen.

\section{Inleiding}

De code Tabaksblat begint effect te sorteren. Enige tijd geleden heeft supermarktconcern Ahold als eerste Nederlandse Vennootschap aangegeven dat zij gaat voldoen aan de code voor goed ondernemingsbestuur. En passant nam Ahold afscheid van twee van haar commissarissen omdat zij naar de letter van de code niet onafhankelijk zouden zijn. De onafhankelijkheid van commissarissen is een sleutelbegrip in de code Tabaksblat, overigens net als in vele corporate governance codes elders in de wereld. Dat de raad van commissarissen ( $\mathrm{RvC}$ ) zo in de belangstelling staat, is niet verwonderlijk gelet op wat er zich heeft afgespeeld bij onder andere Enron, Ahold en Parmelat. Het begrip onafhankelijkheid verwijst in dit verband naar de relatie tussen de raad van bestuur ( $\mathrm{RvB}$ ) en de RvC. In dit artikel wordt onafhankelijkheid van de raad van commissarissen opgevat in de (tweede) betekenis van Moerland (2000, p. 324), namelijk onafhankelijk van hen over wie het toezicht wordt uitgeoefend. De gangbare opvatting is dat een onafhankelijke $\mathrm{RvC}$ een

Dr. T.J.B.M. Postma is als universitair hoofddocent Strategisch Management verbonden aan de Faculteit Bedrijfskunde van de Rijksuniversiteit Groningen.

Prof. Dr. H. van Ees is als hoogleraar Economische Theorie en Onderwijs verbonden aan de Faculteit der Economische Wetenschappen van de Rijksuniversiteit Groningen. De in dit artikel ontwikkelde ideeën zijn mede tot stand gekomen in een workshop over 'board research' gehouden aan de Norwegian School of Management BI te Oslo op 11 februari 2004. De auteurs zijn de deelnemers aan deze workshop erkentelijk voor hun inbreng. 
conditie sine qua non is voor een adequate uitoefening van de toezichthoudende taak van de RvC.

Het is om meerdere redenen interessant om het begrip onafhankelijkheid, zoals het in de code Tabaksblat wordt uitgewerkt, aan een nadere analyse te onderwerpen. In de eerste plaats omdat wetenschappelijk onderzoek laat zien dat wereldwijd het belang van de $\mathrm{RvC}$ als instituut ter bewaking van goed ondernemingsbestuur toeneemt in vergelijking met andere 'corporate governance'-instituties. Een goed inzicht in het functioneren van de $\mathrm{RvC}$ in relatie tot de RvB behoort tot de kern van het onderwerp 'corporate governance'. In de tweede plaats omdat men op ten minste twee manieren het functioneren van de RvC kan beschouwen. Allereerst kan de legitimiteit van het functioneren van de $\mathrm{RvC}$ het onderwerp van studie zijn. Vanwege het normerende karakter hebben codes, en meer in het bijzonder het naleven ervan, een positief effect op de legitimiteit van het handelen van de RvC. Daarnaast kan de effectiviteit van het functioneren van de $\mathrm{RvC}$ worden geanalyseerd, het onderwerp van dit artikel. De recente literatuur op dit gebied laat een verschuiving zien naar onderzoek dat de besluitvormingsprocessen van RvC's probeert te begrijpen in relatie tot het effectief functioneren van RvC's. Op basis van deze literatuur kan worden geconcludeerd dat de kwaliteit van de besluitvorming gebaat is bij de aanwezigheid van 'onafhankelijke denkers'. Het is echter vooralsnog een open vraag in hoeverre de onafhankelijke commissarissen in de zin van de code Tabaksblat het onafhankelijke denken daadwerkelijk in de $\mathrm{RvC}$ stimuleren.

Wij vragen ons in dit artikel allereerst af in hoeverre de aanbevelingen en 'best practices' die naar voren komen in de code met betrekking tot onafhankelijkheid van commissarissen kunnen worden onderbouwd door de resultaten van wetenschappelijk onderzoek. Vervolgens gaan we in op de vraag in hoeverre een aanvullende of alternatieve interpretatie van het begrip 'onafhankelijkheid' mogelijk is. Uiteindelijk mondt onze analyse uit in een aantal ideeën en conclusies omtrent de wijze waarop het begrip onafhankelijkheid in de discussie over 'good corporate governance' zou kunnen worden gehanteerd.

Dit artikel is als volgt opgebouwd. In paragraaf 2 bespreken we onderzoek naar de determinanten van de effectieve RvC. In paragraaf 3 gaan we nader in op de literatuur die de effectiviteit van de besluitvorming in de $\mathrm{RvC}$ tot onderwerp van analyse heeft. Paragraaf 4 gaat in op de relatie tussen deze literatuur en de gehanteerde formulering met betrekking tot onafhankelijkheid in de code Tabaksblat, waarna het artikel in paragraaf 5 wordt afgesloten met enkele beschouwingen en conclusies over de vermeende 'onafhankelijkheid' van commissarissen.

\section{Verschuiving onderzoek RvC's}

Er is veelvuldig onderzoek gedaan naar (de effectiviteit van) het functioneren van de $\mathrm{RvC}^{1}$. In de Angelsaksische context betreft dit veelal onderzoek naar de zogenaamde 'unitary board'. Een dergelijke Raad bestaat uit een aantal leden van het topmanagement aangevuld met mensen van buiten, die al dan niet een meer onafhankelijke positie bekleden ten opzichte van het zittende management. In het Verenigd Koninkrijk is de voorzitter van de Raad doorgaans niet dezelfde persoon als de voorzitter van het topmanagement team (ook wel aangeduid als CEO-nonduality). In de Verenigde Staten is 'CEOduality' daarentegen een belangrijk kenmerk van de Raad. In landen als Nederland, Frankrijk en Duitsland houdt de 'supervisory board' (in Nederland de RvC) vooral toezicht op het topmanagement. Het topmanagement en de 'supervisory board' hebben verschillende taken, bevoegdheden en verantwoordelijkheden en er bestaan geen personele unies tussen beide. In het vervolg van dit artikel duiden we met het begrip 'de Raad', afhankelijk van de institutionele context, zowel op de Angelsaksische 'unitary board' als op de continentaal Europese 'supervisory board'.

\section{De relatie tussen de kenmerken van de Raad en de pres- taties van de onderneming}

Veel empirisch onderzoek naar de effectiviteit van de Raad stamt uit de Verenigde Staten. Dergelijk onderzoek richtte zich in hoofdzaak op de kenmerken van de Raad in relatie tot de effectiviteit van haar functioneren. Bij kenmerken denken we aan de omvang en de samenstelling van de Raad (bijvoorbeeld de ratio 'insiders/outsiders', recentelijk aangevuld met 'quasioutsiders', dat zijn personen die semi-onafhankelijk zijn zoals organisatieadviseurs, of de ratio vrouwen/ mannen) en de omvang van de Raad (het aantal leden, alsmede de optimale grootte). Een tweede categorie kenmerken betreft de structuur van de Raad: met name 'CEO-duality' en het bestaan van subcommissies (als de nominatie-, de audit-, en de beloningscommissie). Een derde categorie bestudeert de gevolgen voor effectief functioneren van een verschillende beloning van leden van de Raad in termen van aandelen, bonussen en opties. De vierde en laatste categorie omvat onderzoek naar de effectiviteit van meer per- 
soonlijke kenmerken (opleiding, ervaring, achtergrond en deelname aan andere Raden). Merk op dat veel van dergelijke constructen op enigerlei wijze het concept 'de onafhankelijke Raad' proberen te operationaliseren. Zo wordt een raad met veel 'outsiders' onafhankelijker geacht. Hetzelfde geldt voor een Raad waarvan de voorzitter niet de CEO is (CEO-nonduality). Om de effectiviteit van het functioneren van de Raad te meten, worden deze kenmerken veelal direct in verband gebracht met de prestatie van de vennootschap (gebruikmakend van accounting maatstaven zoals Return in Investment (ROI), Return on Assets (ROA), Return on Equity (ROE), of samengestelde maatstaven en daarnaast ook meer marktgerichte maatstaven zoals Tobin's Q of de koers van het aandeel, zie pijl 3 in Figuur 1).

\section{Problemen met de Black box-benadering}

Uitgebreid literatuuronderzoek leert dat deze Black box-benadering niet tot eenduidige resultaten leidt (Van Ees en Postma, 2003, Hermalin en Weisbach, 2001 en Dalton et al., 1999). Om een aantal redenen zijn genoemde kenmerken niet in verband te brengen met de prestatie van de onderneming.

- In de eerste plaats is de literatuur zelf niet eenduidig in haar theoretische proposities. Zo kan een kleinere Raad de efficiëntie van de besluitvorming weliswaar vergroten (lagere coördinatiekosten), maar hoeft de kwaliteit van de besluitvorming (dit in verband met ontbrekende kennis en bekwaamheden) niet noodzakelijkerwijs toe te nemen.

- In de tweede plaats kunnen vraagtekens worden gesteld bij de exogeniteit van sommige constructen (Hamilton en Nickerson, 2003). Zo is in de relatie tussen omvang van de Raad en de ondernemingsprestatie, de 'omvang' niet persé een onafhankelijke variabele, maar kan deze zeer wel resultante zijn van een onderhandelingsproces met aandeelhouders.

- In de derde plaats is de causaliteit niet altijd eenduidig (Hermalin en Weisbach, 2001), de kenmerken van de Raad kunnen het gevolg zijn van keuzes en bijvoorbeeld mede het gevolg zijn van (tegenvallende) ondernemingsprestaties (dit zien we bijvoorbeeld ten onzent gebeuren bij Ahold). Dit betekent dat uitspraken of richtlijnen omtrent de gewenste (scores op de) kenmerken van de Raad in relatie tot de effectiviteit van het functioneren, zoals bijvoorbeeld de formele onafhankelijkheid van commissarissen, niet met behulp van wetenschappelijk onderzoek kunnen worden onderbouwd. Daartoe is nodig het functioneren van de Raad zelf expliciet tot onderwerp van analyse te maken. De Black box van het functioneren omvat de wijze waarop leden van de Raad met elkaar omgaan en de rollen die ze spelen ten opzichte van het topmanagement. De bovenstaande discussie wordt in figuur 1 samengevat.

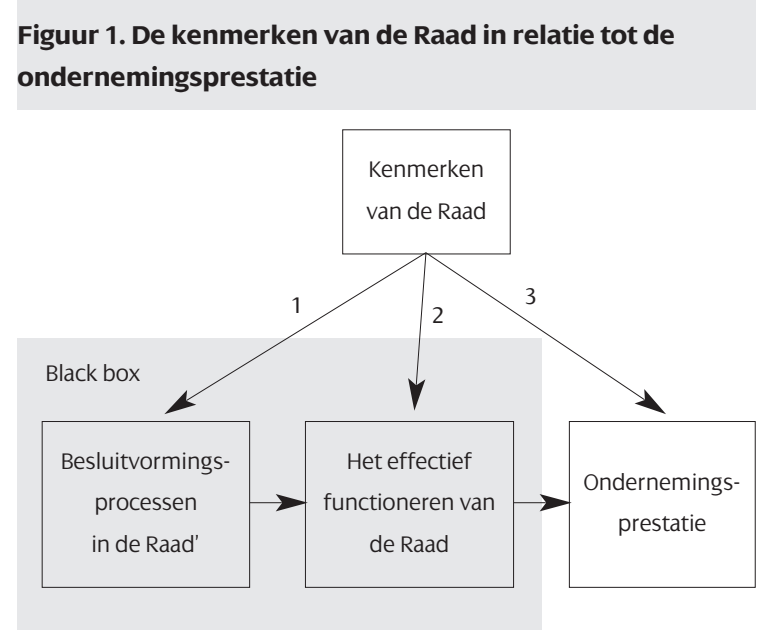

De discussie omtrent de inhoud van de Black box volgt in de volgende paragraaf.

\section{Openen van de Black box van de Raad}

\subsection{Rollen van de Raad}

In de literatuur over 'corporate governance' wordt het effectief functioneren van de Raad ('board performance') doorgaans geassocieerd met de verschillende rollen die de Raad kan spelen (Zahra en Pearce, 1989; Goodstein et al., 1994; Van Ees en Postma, 2002).

\section{Toezichtrol}

De eerste rol betreft de toezichtrol van de Raad. Vanuit de principaal-agenttheorie kan deze toezichtrol worden onderbouwd; de Raad wordt opgevat als een efficiënte oplossing voor het agentschapprobleem tussen enerzijds eigenaren (aandeelhouders) en andere belangengroepen en anderzijds het management van de vennootschap (Fama en Jensen, 1983; Tirole, 1999). De Raad houdt toezicht ten behoeve van de aandeelhouders en overige belanghebbenden. Door het uitoefenen van toezicht reduceert de Raad de agentschapkosten (Zahra en Pearce, 1989). De Raad fungeert als een instituut dat strategische beslissingen ratificeert, controle uitoefent op het topmanagement en topmanagement kan benoemen, schorsen of ontslaan (Barnhart et al., 1994). Om het toezicht naar behoren te kunnen uitoefenen is een onafhankelijke, 
objectieve houding van de Raad een noodzakelijke, maar geenszins voldoende, voorwaarde. In de beleidsdiscussie staat 'onafhankelijkheid' in dit verband voor 'buitenstaander', in de zin van geen directe relatie hebbend met het topmanagement en de onderneming. De kritische distantie van commissarissen zou zich slecht verhouden met relaties en belangen in het bedrijf. In de Nederlandse context is dat voor de onderneming die onder het structuurregime valt ook wettelijk vastgelegd (Van Manen, 1999). Ook de code Tabaksblat hanteert dezelfde formele interpretatie van het begrip 'onafhankelijkheid'. Opgemerkt kan worden dat de relatie tussen deze onafhankelijkheid en de effectiviteit van het toezicht niet zonder problemen is (Boot en Macey, 2001). Ten einde de toezichtrol goed te kunnen vervullen, dient de $\mathrm{RvC}$ niet alleen onafhankelijk maar tevens deskundig en goed geïnformeerd te zijn. Te veel distantie vermindert de kwaliteit van het toezicht vanwege onvolledige informatie en expertise. Een buitenstaander kan dan onvoldoende toezicht uitoefenen doordat hij/zij onvoldoende op de hoogte is.

\section{Adviesrol}

De tweede rol van de Raad is de adviesrol. Deze rol kan worden onderbouwd met behulp van de managementliteratuur, met name de 'Resource Dependency'theorie en de 'Resource-Based View'. Eerstgenoemde theorie benadrukt dat een onderneming afhankelijk is van externe middelen (Pfeffer en Salancik, 1978). De leden van de Raad vervullen in deze benadering een netwerkfunctie door het creëren en onderhouden van relaties met voor de onderneming belangrijke externe partijen als banken, toeleveranciers, andere relevante bedrijven en de overheid (Chirinko et al., 2004). De 'Resource-based View' heeft betrekking op de unieke, niet-imiteerbare en schaarse activa en vaardigheden die een onderneming een duurzaam concurrentievoordeel verschaffen (Barney, 1991). Deze theorie geeft aan dat de Raad zelf ook een 'Resource' kan zijn. Hillman en Dalziel (2003) spreken in dit verband van het kapitaal van de Raad ('board capital'). Als zodanig kan de Raad optreden als adviseur, klankbord, speurhond voor het aantrekken van topmanagers en meedenken in strategievormingsprocessen (Wijbenga et al., 2003). In deze rol staat samenwerking met het topmanagement, het vertrouwen in en de betrokkenheid bij de onderneming voorop. De effectiviteit van de adviesrol wordt doorgaans positief beïnvloed indien commissarissen betrokken zijn bij de onderneming en een vertrouwensrelatie met het topmanagement hebben opgebouwd.

Daarmee kunnen we concluderen dat de combinatie van beide rollen in de Raad problematisch kan zijn. Commissarissen worden geacht tegelijkertijd onafhankelijk, objectief, coöperatief, interdependent en samenwerkingsbereid te zijn (Sundaramurthy en Lewis, 2003). Bovendien kan worden opgemerkt dat de nadruk op de verschillende rollen kan verschillen naar gelang de ontwikkelingsfase of de complexiteit van de problematiek van de onderneming (Huse, 1998; Lynall et al., 2003). Dergelijke tegenstellingen in het effectief functioneren van de Raad spelen in de beleidsdiscussie in Nederland over de vormgeving van de $\mathrm{RvC}$ echter nauwelijks een rol. Tegelijkertijd bieden deze kenmerken ook een verklaring voor het niet-eenduidige karakter van de conclusies van het wetenschappelijk onderzoek. De rol van de $\mathrm{RvC}$ in het ondernemingsbestuur kan niet worden gereduceerd tot eenvoudige relaties tussen objectieve kenmerken van de Raad enerzijds en de prestaties van de onderneming anderzijds. Om wetenschappelijke uitspraken te kunnen doen is (meer) inzicht in het daadwerkelijk functioneren van de Raad noodzakelijk (zie pijl 2 in figuur 1).

\subsection{Onderzoek naar het functioneren van de Raad}

De rollen van de Raad en de effectiviteit ervan hangen ten principale samen met de manier waarop de leden van de Raad met elkaar en met het management omgaan (Westphal, 1999). Het onderzoek naar deze 'omgangsvormen' richt zich op de activiteiten en besluitvormingsprocessen in de Raad (Zahra en Pearce, 1989; Pettigrew, 1992), alsmede de relatie tussen kenmerken van de Raad en deze variabelen (pijl 1 in figuur 1). Voorbeelden van dergelijk meer beschrijvend onderzoek zijn Pettigrew en McNulty (1999), Stiles en Taylor (2001) en Gabrielsson en Huse (2002), die verslag doen op basis van participerende observatie (in 'boardrooms'), diepte-interviews met commissarissen en schriftelijke documenten (zoals notulen). Ook is er meer conceptueel onderzoek op dit gebied. Zo proberen Forbes en Milliken (1999) de besluitvormingsprocessen in de Raad te bestuderen met behulp van relaties tussen concepten die de normering van inzet ('effort norms'), de aanwezigheid en het gebruik van kennis, de aard van conflicten (cognitief dan wel affectief) en de cohesie tussen de leden van de Raad beschrijven. Daarbij werken zij een relatie uit tussen de kenmerken van de Raad, de besluitvormingsprocessen en het effectief functioneren van de Raad (pijlen 1 en 2 in figuur 1). Onder meer Huse (1993; 1999; 2002), Westphal (1999) en Van Ees en Postma (2003) besteden aandacht aan de invloed van vertrouwen en sociale normen op de relatie tussen 
bestuurders en commissarissen enerzijds en de effectiviteit van de besluitvorming in de Raad anderzijds. Ook de speciale juni 2003-uitgave van het toptijdschrift Academy of Management Review (2003) is bijna geheel aan dergelijk onderzoek gewijd. Overigens kan ook van dit onderzoek worden gesteld dat in dit vroege stadium van ontwikkeling nog geen baanbrekende empirische resultaten zijn geboekt. Wel is er enige ondersteuning voor de stelling dat genoemde (proces)variabelen van invloed zijn op de (effectiviteit van de) activiteiten van de Raad. Daarmee kan mogelijk tegemoet gekomen worden aan een aantal van de bezwaren die gelden voor de eerder genoemde Black box-benadering, die uitgaat van een directe relatie tussen de kenmerken van de Raad en de prestaties van de vennootschap.

\section{'Board'-onderzoek en de Commissie Tabaksblat}

Ons inziens zijn de bovenstaande wetenschappelijke bevindingen van belang voor de discussie over de code Tabaksblat'. In deze 'Nederlandse corporate governance code' worden met name de Raad van Bestuur, de Raad van Commissarissen en de Algemene Vergadering van Aandeelhouders en hun onderlinge relaties belicht. De code bevat onder meer aanbevelingen inzake rollen en procedures, de onafhankelijkheid van commissarissen, deskundigheid en samenstelling van de Raad, de rol van de voorzitter en de secretaris, samenstelling en rol van subcommissies, conflicterende belangen tussen de onderneming en commissarissen, beloning en ten slotte de structuur van de Raad. Op grond van de discussie in beide voorgaande paragrafen stellen wij dat de resultaten van empirisch onderzoek vooralsnog weinig houvast bieden voor de meeste aanbevelingen. Veel onderzoek betreft relatie 3 in figuur 1. Op basis hiervan is het moeilijk om tot eenduidige aanbevelingen te komen. De code Tabaksblat betreft overigens hoofdzakelijk relatie 2. Probleem daarbij is dat een directie relatie tussen de kenmerken en procedures van de Raad en de effectiviteit van het functioneren van de Raad niet kan worden gelegd. Ons inzicht in de relevante literatuur leert dat slechts sprake kan zijn van een indirecte relatie, die loopt via de onderliggende besluitvormingsprocessen. Voor een adequate onderbouwing van de relatie tussen de richtlijnen van de code Tabaksblat en de effectiviteit van de activiteiten van de Raad zou de code richtlijnen moeten bevatten omtrent de besluitvormingsprocessen zelf en de gedragingen van de leden van de Raad gedurende de besluitvorming. We willen het belang van deze bena- dering adstrueren aan de hand van de discussie over onafhankelijkheid van leden van de Raad.

\subsection{Code Tabaksblat en onafhankelijkheid}

De code Tabaksblat geeft aan dat de kenmerken (samenstelling) van de Raad van dien aard moeten zijn dat commissarissen kritisch en onafhankelijk van elkaar en van het management kunnen functioneren (en van andere bepaalde belangen). Een commissaris wordt onafhankelijk geacht indien hij of zijn echtgenoot, geregistreerde partner of andere levensgezel, pleegkind, of bloed- of aanverwant tot in de tweede graad niet voldoet aan een verzameling van kenmerken (criteria). Deze kenmerken zijn samen te vatten als het hebben van een werkrelatie (tot vijf jaar geleden) met de onderneming, het ontvangen van persoonlijke financiële compensatie van de onderneming (of een geassocieerde onderneming), het hebben van een belangrijke zakelijke relatie met de onderneming (of een geassocieerde onderneming), bestuurslid zijn van een onderneming, waarin een bestuurslid van de onderneming waarop hij toezicht houdt commissaris is, het hebben van ten minste $10 \%$ van de aandelen in de onderneming, het zijn van een bestuurder of commissaris in een onderneming die ten minste $10 \%$ van de aandelen heeft (tenzij het gaat om een groepsmaatschappij) en ten slotte wanneer de persoon de afgelopen 12 maanden tijdelijk heeft voorzien in het management van de onderneming. Het valt ons in het licht van de bovenstaande literatuur op dat de bovenstaande definitie van onafhankelijkheid uitsluitend is gebaseerd op formele kenmerken waaraan een lid van de $\mathrm{RvC}$ zou behoren te voldoen om diens toezichthoudende rol naar behoren uit te kunnen voeren. Daarmee is het een benadering die bij uitstek past binnen relatie 2. Echter het is vooralsnog de vraag in hoeverre degelijke formele kenmerken ook daadwerkelijk het gedrag van de commissarissen effectiever (in casu kritischer) maken.

\subsection{Commentaar}

Op basis van onze analyse van de relevante literatuur hebben wij twee opmerkingen.

- In de eerste plaats stellen wij dat de bovenstaande formele kenmerken geenszins garanderen dat de besluitvorming in een dergelijke onafhankelijke RvC gekenmerkt wordt door objectiviteit en kritische distantie van hoge kwaliteit. Bovenstaande kenmerken impliceren immers niet dat commissarissen onafhankelijke denkers zullen zijn. Deze kenmerkendefinitie van afhankelijkheid zegt vrij weinig over onafhankelijk- 
heid in het denken, de manier waarop commissarissen met elkaar omgaan en de aard van de besluitvorming. Om de toezichtrol goed te kunnen vervullen, moeten commissarissen met name mentaal onafhankelijk zijn. Dat houdt onder meer in dat ze goed geïnformeerd zijn over wat er in de betrokken onderneming omgaat. Een effectieve informatievoorziening berust doorgaans op transparantie, open communicatie en zeker niet in de laatste plaats op een gezonde dosis van onderling vertrouwen tussen bestuurders en commissarissen. Zonder vertrouwen is er geen communicatie tussen het bestuur en de raad en het toezicht verre van effectief. Het voeren van debat (cognitief conflict), het gezamenlijk ontwikkelen van normen met betrekking tot de inzet van deskundigheid en de inbreng van kennis en ervaring en het in zijn algemeenheid betrokken zijn bij het wel en wee van de onderneming verhoogt de effectiviteit van de RvC. Sterker nog, we stellen dat commissarissen slechts in staat zijn topmanagers op hun handelen aan te spreken, indien zij betrokken zijn. Betrokken zijn impliceert een open positie in durven nemen, afhankelijk zijn van het handelen van het topmanagement. Voorbeelden voor het bevorderen van betrokkenheid, maar tegelijkertijd voorwaarden voor het creëren van onafhankelijkheid zijn het voor commissarissen formuleren van inspanningsverplichtingen, meer expliciete kennis- en kwaliteitseisen, richtlijnen die erop gericht zijn divergentie (diversiteit) in te brengen in situaties van 'groupthink' en/of te hoge mate van onderling vertrouwen, c.q. juist vertrouwen en consensus te versterken in situaties van conflict en fragmentatie. Met name de rol van de voorzitter van de Raad is bij dit alles van groot belang. 'Board leadership' zou meer pregnant naar voren kunnen komen. Wij denken hierbij aan de invloed op besluitvorming in de Raad en de rolperceptie en -uitoefening door individuele commissarissen. De rol van de voorzitter omvat dan niet alleen formele aspecten (zoals uit de code blijkt), maar ook het inspireren van commissarissen, het bewaken dat de communicatie transparant is, erop gespitst zijn dat stakeholders serieus worden genomen en ten slotte te bevorderen dat de onderneming meer open staat voor de samenleving. Over deze rol en de geformuleerde randvoorwaarden zijn bij uitstek (additionele) richtlijnen te formuleren die beter via een code zijn te bevorderen dan via wet- en regelgeving zijn af te dwingen. Daarnaast gaat de definitie voorbij aan de ook voor Nederland relevante situatie dat onafhankelijkheid in de bovenstaande formele zin heel goed samen gaat met afhankelijkheid in de sociale zin van informele en sociale netwerken. Commissarissen kennen elkaar vanuit verschillende achtergronden en sociale verbanden (studie aan zelfde universiteit of andere opleiding, studievereniging, Rotary/Ronde tafel, commissaris/bestuurder in elkaars onderneming, et cetera; kortom het bekende 'old boys network'). Voor de Nederlandse situatie is dit uitgebreid onderzocht (zie Van Hezewijk en Metze, 1998; Van Hezewijk, 2003).

- In de tweede plaats is uit de literatuur inzake besluitvormingsprocessen in teams bekend dat leden van teams (in dit geval commissarissen (en bestuurders)) door onderlinge interacties steeds meer cohesie gaan vertonen en dat het onderlinge vertrouwen toeneemt. In eerste instantie heeft dit een positief effect op de kwaliteit van de besluitvorming, maar uiteindelijk kan dit resulteren in een te grote mate van onderlinge afstemming ('groupthink'). Dit kan bijvoorbeeld leiden tot te grote mate van meegaandheid van commissarissen met de (dubieuze) handelingen van het topmanagement en een te weinig kritische houding van commissarissen ten opzichte van elkaar (zie de diverse recente NRC-publicaties in het geval van Ahold).

Bovenstaande argumenten illustreren dat personen die onafhankelijk zijn volgens de kenmerkendefinitie van de code, zich materieel gezien wel degelijk afhankelijk kunnen opstellen.

\section{Conclusie en discussie}

In dit artikel is ingegaan op onderzoek naar het effectief functioneren van de Raad. Aangegeven is dat er een verschuiving plaatsvindt in het soort onderzoek. De uitdaging zit momenteel meer in het verkrijgen van inzicht in de besluitvormingsprocessen in de Raad en de dynamiek van deze processen in relatie tot het effectiever functioneren van de Raad. Indien de effectiviteit van de Raad onderwerp van discussie is, dan zal er naast de kenmerken van de Raad ook aandacht moeten worden besteed aan de wijze waarop de besluiten tot stand komen.

Bij codes als die van de commissie Tabaksblat wordt geleund op resultaten van wetenschappelijk onderzoek. Wanneer de resultaten van het onderzoek niet eenduidig zijn, hangen de codes in de lucht. Over het effect van de code op het functioneren van de Raad kunnen in dat geval geen uitspraken worden gedaan. De discussie over de onafhankelijke commissaris onderstreept dit. Opvallend is dat het Higgs-report voor het Verenigd Koninkrijk (Higgs, 2003 plus aanhangsel) ook wat genuanceerder is. Naast een overeenkomstige kenmerkendefinitie als de Nederlandse code, wordt expliciet aanbevolen dat ' $[\ldots$ A nonexecutive director is considered independent when the 
board determines that the director is independent in character and judgement, and there are no relationships or circumstances which could affect or appear to affect, the directors judgement ....... The board should identify in its annual report the non-executive directors it determines to be independent.'; p. 81/82]. McNulty et al. (2003), die voor het Higgs-report een 40-tal interviews hebben gehouden met commissarissen in het Verenigd Koninkrijk geven in dit verband aan dat onafhankelijkheid betekent 'dingen anders zien'. Mentale onafhankelijkheid betreft het vermogen van commissarissen om het denken van bestuurders te testen en uit te dagen op basis van hun ervaringen elders (p. 5). In deze zin wordt onafhankelijkheid meer een 'vaardigheid' zoals in paragraaf 3 al werd aangegeven in de context van 'Resource Based View', dan een kenmerk, zoals beschreven in de code. Ook gaat het hier meer om de cultuur van de Raad, die open discussies en dialoog stimuleert en waardeert, ook al is er sprake van een commissaris als grootaandeelhouder of familierelatie. In deze zin kan de effectiviteit van de Raad en de wijze waarop dat terugkomt in de gehanteerde Raadrollen, worden verhoogd.

\section{Ten slotte}

Codes hebben een belangrijke rol op het gebied van 'corporate governance' vanwege de legitimerende functie. Zeker in een periode waarin het vertrouwen van de stakeholders in het bestuur en toezicht van de onderneming tanende is, is een hernieuwde legitimering van de rol van de Raad wenselijk. Bij het vraagstuk van de legitimiteit speelt echter vooral een rol in hoeverre de code (en de naleving) ervan aansluit bij de gevestigde opinie. Het is van belang op te merken dat het vraagstuk van effectief functioneren van een andere orde is. Codes kunnen legitiem en tegelijkertijd ineffectief zijn. Evenzo kan effectief gedrag niet legitimiteit zijn. In dit artikel hebben we betoogd dat niettegenstaande het aspect van de legitimiteit, wij vraagtekens zetten bij de effectiviteit van de formele behandeling van het begrip onafhankelijkheid in de code Tabaksblat. Naar onze mening zou een vervolgcode in analogie met het Higgs-rapport - naast een omschrijving van het begrip (on)afhankelijkheid - ook meer in kunnen gaan op de manier waarop commissarissen in dit verband met elkaar en met de RvB omgaan en in hun onderlinge processen het begrip onafhankelijkheid vormgeven. We raken hier overigens wel aan de grenzen van wat een code nog vermag. Codes scheppen weliswaar de voorwaarden voor effectief handelen maar kunnen niet voorschrijven hoe in de praktijk mensen met elkaar omgaan. Overigens kunnen wij ons ook in dit ver- band vinden in de aanbevelingen van het Higgs-rapport, waarin wordt gepleit voor meer aandacht voor de introductie, opleiding en ontwikkeling van commissarissen.

\section{Literatuur}

Barnhart, S.W., M.W. Marr en S. Rosenstein, (1994), Firm Performance and Board Composition: Some New Evidence, in: Managerial and Decision Economics, Vol. 15, No. 4, pp. 329-340

Barney, J., (1991), Firm resources and sustained competitive advantage, in: Journal of Management, Vol. 17, No. 1, pp. 99-120.

Boot, A.W.A. en J.R. Macey, (1999), Objectivity, Proximity and Adaptability in Corporate Governance, Paper Presented in Groningen.

Chirinko, B., H. van Ees, H. Garretsen en E. Sterken, (2004), Investor Protections, Concentrated Ownership, and Other Corporate Control Mechanisms in the Netherlands, in: German Economic Review, Vol. 5, No. 2, pp. 119-138

Commissie Corporate Governance, (2003), De Nederlandse Corporate Governance Code: Beginselen van deugdelijk ondernemingsbestuur en best practice bepalingen, 9 december.

Dalton, D.R., C.M. Daily, A.E. Ellstrand en J.L. Johnson, (1998), MetaAnalytic Reviews of Board Composition, Leadership Structure, and Financial Performance, in: Strategic Management Journal, Vol. 19, No. 3 , pp. 269-290.

Dalton, D.R., C.M. Daily, J.L. Johnson en A.E. Ellstrand, (1999), Number of Directors and Financial Performance: A Meta-Analysis, in: Academy of Management Journal, Vol. 42, No. 6, pp. 674-686.

Ees, H. van en Th. Postma, (2002), An Equilibrium Interpretation of the Relationship between Board Size and Corporate Performance, Paper presented at EURAM, April 9, Stockholm.

Ees, H. van en Th. Postma, (2003), Board Processes and (Non)sense of CEOduality, Paper presented at EURAM, 3-5 April, Bocconi University, Milan.

Fama, E.F. en M.C. Jensen, (1983), Separation of Ownership and Control, in: Journal of Law and Economics, Vol. 26, No. 2, pp. 301-325.

Forbes, D.P. en F.J. Milliken, (1999), Cognition and Corporate Governance: Understanding Boards of Directors as Strategic Decision-Making Groups, in: Academy of Management Review, Vol. 24, No. 3, pp. 489-505.

Gabrielsson, J. en M. Huse, (2002), The venture capitalist and the board of directors in SMEs: roles and processes, in: Venture Capital, Vol. 4, No. 2 , pp. 125-146.

Goodstein, J., K. Gautam, W. Boeker, (1994), The Effects of Board Size and Diversity on Strategic Change, in: Strategic Management Journal, Vol. 15, No. 3, pp. 241-250

Hamilton, B.H. en J.A. Nickerson, (2003), Correcting for Endogeneity in Strategic Management Research, in: Strategic Organization, Vol. 1, No. 1, pp. 51-78.

Hermalin, B.E. en M.S. Weisbach, (1998), Endogenously Chosen Boards of Directors and their Monitoring of the CEO, in: American Economic Review, Vol. 88, No. 1, pp. 96-118.

Hermalin, B.E. en M.S. Weisbach, (2001), Boards of Directors as an Endogenously Determined Institution: A Survey of the Economic Literature, NBER Working Paper, 8161.

Hezewijk, J. van, (2003), De nieuwe elite van Nederland, Balans, Amsterdam. 
Hezewijk, J. van en M. Metze, (1998), XXL: De macht, netwerk, de prestaties en de wereld van Nederlandse topmanagers, SUN, Nijmegen.

Higgs, D., (2003), Review of the Role and Effectiveness of Non-Executive Directors, January.

Higgs, D., (2003), Annex A: Suggested Revised Code (Incorporating Review Recommendations), Part I Principles of Good Governance.

Hillman, A.J. en T. Dalziel, (2003), Boards of Directors and Firm Performance: Integrating Agency and Resource Dependence Perspectives, in: Academy of Management Review, Vol. 28, No. 3, pp. 383-396.

Huse, M., (1993), Relational Norms as a Supplement to Neo-Classical Understanding of Directorates: An Empirical Study of Boards of Directors, in: Journal of Socio-Economics, Vol. 22, No. 3, pp. 219-240.

Huse, M., (1998), Researching the dynamics of board-stakeholder relations, in: Long Range Planning, Vol. 31, No. 2, pp. 218-226.

Huse, M., (1999), The Role of Trust in Empowering Boards of Directors: Researching 'Unresearchable' Issues, Paper Presented at the Academy of Management Meeting in Cincinnati, August, 1996, Adapted 1999.

Huse, M., (2002), The Value Creating Board: Revisiting the Governance Performance Links, Paper presented at the Corporate Governance Conference at Bocconi University, December 8.

Lynall, M.D., B.R. Golden en A.J. Hillman, (2003), Board Composition from Adolescence to Maturity: A Multitheoretic View, in: Academy of Management Review, Vol. 28, No. 3, pp. 416-431.

Manen, J. van, (1999), Monitor in het belang van de vennootschap (dissertatie), Elsevier, Groningen.

McNulty, J. Roberts en P. Stiles, (2003), Creating accountability within the board: The work of the effective non-executive director (A Report for the Review of the Role and Effectiveness of the Non-Executive Director conducted by Mr. Derek Higgs), Unpublished Paper, Leeds University Business School.

Moerland, P. (2000), Onafhankelijkheid van Ondernemingstoezicht, in: Maandblad voor Accountancy en Bedrijfseconomie, Vol. 74, No. 7/8, pp. 324-332.

NRC, (2004), artikelen inzake Ahold op respectievelijk 14/16/17 en 21 februari 2004.

Pettigrew, A., (1992), On Studying Managerial Elites, in: Strategic Management Journal, Vol. 13, No. 8, pp. 163-182.

Pettigrew, A. en T. McNulty, (1999), Strategists on the Board, in: Organization Studies, Vol. 20, No. 1, pp. 47-74.

Pfeffer, J. en G.R. Salancik, (1978), The External Control of Organizations, Harper \& Row, New York.

Stiles, P. and B. Taylor, (2001), Boards at Work: How directors view their roles and responsibilities, Oxford University Press, Oxford

Sundaramurthy, C. en M. Lewis, (2003), Control and Collaboration: Paradoxes of Governance, in: Academy of Management Review, Vol. 28, No. 3, pp. 397-415.

Tirole, J., (1999), Corporate Governance, in: Econometrica, Vol. 69, No. 1, pp. 1-35.

Westphal, J.D., (1999), Collaboration in the boardroom: The consequences of social ties in the CEO/board relationship, in: Academy of Management Journal, Vol. 42, No.1, pp.7-24.

Wijbenga, F.H., Th.J.B.M. Postma, A. van Witteloostuijn en P.S. Zwart,
(2003), Strategy and Performance of Venture Capital-Backed SMEs, in: Venture Capital journal, Vol. 5, No. 3, pp. 231-250.

Zahra, S.A. en J.A. Pearce, (1989), Boards of Directors and Corporate Financial Performance: A Review and Integrative Model, in: Journal of Management, Vol.15, No. 2, pp. 291-334.

\section{Noten}

1 Zie ondermeer Dalton et al. (1998; 1999), Hermalin en Weisbach (1998; 2001 ) en Stiles en Taylor (2001).

2 Deze commissie is op 10 maart 2003 geïnstalleerd in opdracht van Euronext (Amsterdam), de NCD, de SCGOP, de VEB, de VEUO, VNO-NCW en op verzoek van de ministers van Financiën en Economische Zaken. Op 9 december 2003 zijn haar aanbevelingen gepubliceerd (zie Commissie Corporate Governance, 2003). 